\title{
Which competences for sub-national jurisdictions and how to finance them? The economic theory of fiscal federalism from the foundations to nowadays
}

\author{
Maxime Uhoda $\square$ \\ Journal of Social and Economic Development (2020) | Cite this article \\ Metrics
}

\begin{abstract}
This paper describes the evolution of the recommendations resulting from the theory of fiscal federalism concerning material and fiscal competences. More precisely, this article will develop the theoretical arguments that will make it possible to judge which competences are best managed at which level of power and how best to finance them. I shall firstly describe the content of the major State functions, as well as classic and new recommendations for the distribution of competences between levels of power. I will then develop classic and new ideas about different ways, for a decentralized state, of organizing the financing of federated and/or decentralized jurisdictions. The balance between equity and efficiency considerations will often lead to acceptable solutions. The growing importance of "global” public goods such as environmental protection must also be considered. Finally, responses to regionalist aspirations have opened original ways of decentralizing material and fiscal powers.
\end{abstract}

Full-text view-only version : https://rdcu.be/b3YRI 